\title{
Analysis of Starch Grains Produced in Select Taxa Encountered in Southwest Asia
}

\author{
Thomas C. Hart \\ Author address: Department of Anthropology, University of Texas, 2201 Speedway C3200, University of Texas at Austin, \\ Austin, Texas, 78712, U.S.A. \\ Email: thomas.hart@utexas.edu
}

Received: September 13, 2014

Volume: 5:135-145

Published: December 15, 2014

(C) 2014 Society of Ethnobiology

\begin{abstract}
Starch grain analysis is a rapidly growing field of archaeological research in Southwest Asia. However, much work still remains regarding which taxa produce starch grains that can be identified in the archaeological record. In this paper, I centralize what is known about starch production patterns within regional flora and analyze 64 previously unstudied taxa from 22 families. The results of this study demonstrate that descriptions of starch grains from Southwest Asian taxa are scattered between archaeological and plant and food science publications. Ten of the species examined in this study, most of whom are grasses, produced starch grains that can be identified at varying taxonomic levels.
\end{abstract}

Keywords: Paleoethnobotany, Starch Grains, Southwest Asia

\section{Introduction}

Recent starch grain analysis in Southwest Asia has provided insight into new areas of research such as beer brewing in ancient Egypt (Samuel 1996) and the diets of middle Holocene farmers (Henry and Piperno 2008), Upper Paleolithic hunters and gatherers (Piperno et al. 2004), and Neanderthals (Henry et al. 2011). Despite these promising strides in archaeological research, much remains to be done in regards to discovering which plants produce starches in Southwest Asia and whether or not these starch grains can be used to aid archaeological and paleoecological endeavors. In this paper I seek to understand the research potential of archaeological starch grain research in Southwest Asia by: 1) centralizing where starch grain information about Southwest Asian taxa can be found; 2) examining 64 previously unstudied taxa from 22 families to assess their production patterns; and 3) examining the diagnostic potential of starches found in these new taxa if present.

Organization of Comparative Southwest Asian Publications

The most comprehensive and detailed information about Southwest Asian taxa are embedded within archaeological site reports from this region. These publications provide the best source of data because they cover almost all of the domesticated Southwest
Asian taxa except for Triticum durum Desf. (durum wheat), Triticum compactum L. (club wheat), Hordeum distichon L. (two-rowed barley), and Vicia ervilia (L.) Willd. (bitter vetch) and numerous wild grasses (Henry et al. 2011; Henry and Piperno 2008; Piperno et al. 2004). Unfortunately, not all of these publications provide detailed descriptions of the taxa they discuss despite their pioneering endeavors. Having thorough descriptions of starch producing taxa included in publications provides information about which taxa do and do not produce starches thereby helping researchers in identifying their own archaeological starch materials.

Southwest Asian taxa are also described in archaeological publications from other parts of the world either because these taxa were introduced to the region or because their natural distribution overlaps with that of Southwest Asia. For example, Yang and Perry (2013) analyze starch grains from the tribe Triticeae that grow in north China. These taxa include introduced Southwest Asian domesticates, such as Triticum aestivum L. (bread wheat), and wild taxa that are native to both China and Southwest Asia, such as Aegilops tauschii Coss. (Tauschs goatgrass). A list of publications detailing starch grains from Poaceae taxa that grow in Southwest Asia can be found in Table 1. 
Table 1. Poaceae (Gramineae) taxa that have been published. Note, not all of these publications include descriptions of optical properties.

\begin{tabular}{|c|c|}
\hline Genus and Species & Source \\
\hline Aegilops bicomis (Forsk.) Jaub. \& Spach. & Henry et al., 2011 \\
\hline Aegilops caudate auct. & Reichert, 1913 \\
\hline Aegilops geniculata Roth & Piperno et al., 2004 \\
\hline Aegilops peregrina (Hackel) Maire et Weiler & Piperno et al., 2004 \\
\hline Aegilops speltoides Tausch & Henry et al., 2011 \\
\hline Aegilops truincialis $\mathrm{L}$. & Reichert, 1913 \\
\hline Agropyron cristatum (L.) Gaertn. & Reichert, 1913 \\
\hline Agropyron rigidum (Schrad.) P. Beauv. & Reichert, 1913 \\
\hline Agrostis spica-venti L. & Reichert, 1913 \\
\hline Aira caespitosa $\mathrm{L}$. & Reichert, 1913 \\
\hline Alopecurus arundinaceus Poir & Piperno et al., 2004 \\
\hline Alopecurus geniculatus L. & Reichert, 1913 \\
\hline Alopecurus utriculatus Banks \& Sol. & Piperno et al., 2004; Reichert, 1913 \\
\hline Alopecurus pratensis $\mathrm{L}$. & Reichert, 1913 \\
\hline Avena barbata Pott ex Link & Piperno et al., 2004 \\
\hline Avena sterilis $\mathrm{L}$. & Henry et al., 2011 \\
\hline Brachypodium distachyon (L.) P.Beauv. & Piperno et al., 2004 \\
\hline Bromus brachystachys Hornung & Reichert, 1913 \\
\hline Bromus pseudobrachystachys H. Scholz & Piperno et al., 2004 \\
\hline Bromus squarrosus L. & Reichert, 1913 \\
\hline Gastridium ventricosum (G. australe) (Gouan) Schinz \& Thell. & Piperno et al., 2004; Reichert, 1913 \\
\hline Hordeum bulbosum L. & Piperno et al., 2004 \\
\hline Hordeum glaucum Steudel & Henry et al., 2011; Piperno et al., 2004 \\
\hline Hordeum hexastichon $\mathrm{L}$. & Henry et al., 2011 \\
\hline Hordeum marinum Huds. & Piperno et al., 2004 \\
\hline Hordeum sativum var. (Champion) Jess. & Reichert, 1913 \\
\hline Hordeum spontaneum $\mathrm{L}$. & Henry et al., 2011; Piperno et al., 2004 \\
\hline Hordeum vulgare L. & Henry et al., 2011; Reichert, 1913 \\
\hline Koeleria macrantha (Ledeb.) Schult. & Messner, 2011 \\
\hline Lolium multiflorum Lam. & Piperno et al., 2004 \\
\hline Lolium rigidum Gaudin & Piperno et al., 2004 \\
\hline Lolium temulentum var. speciosum $\mathrm{L}$. & Reichert, 1913 \\
\hline Phalaris minor Retz. & Piperno et al., 2004 \\
\hline Phalaris paradoxa $\mathrm{L}$. & Piperno et al., 2004 \\
\hline Piptatherum holciforme (M.Bieb.) Roem. \& Schult. & Piperno et al., 2004 \\
\hline Poa pratensis $\mathrm{L}$. & Messner, 2011 \\
\hline Poa nemoralis L. & Messner, 2011 \\
\hline Puccinellia distans (Jacq.) Parl. & Piperno et al., 2004 \\
\hline Puccinellia gigantea (Grossh.) Grossh. & Piperno et al., 2004 \\
\hline Secale cereale $\mathrm{L}$. & Reichert, 1913 \\
\hline Secale cereale var. MammothWinter $\mathrm{L}$. & Reichert, 1913 \\
\hline Secale cereale var. Spring $\mathrm{L}$. & Reichert, 1913 \\
\hline Secale cereale ssp. ancestrale $\mathrm{L}$. & Henry et al., 2011 \\
\hline Secale vavilovii Grossh. & Henry et al., 2011 \\
\hline
\end{tabular}

(continued on next page) 
(continued from previous page)

\begin{tabular}{ll}
\hline Genus and Species & Source \\
\hline Triticum aegilopoides (T. monococcum subsp aegilopoides) (Link) Balansa ex & Henry et al., 2011 \\
Körn. & Henry et al., 2011; 2009 \\
Triticum aestivum (T. aestivum ssp aestivum) L. & Reichert, 1913 \\
Triticum dicoccum (T. turgidum ssp. dicoccum) Schrank ex Schübl & Piperno et al., 2004 \\
Triticum dicoccoides Schrank ex Schübl & Reichert, 1913 \\
Triticum monococcum L. & Henry et al., 2011 \\
Triticum monococcum subsp. aegilopoides & Reichert, 1913 \\
Triticum sativum var.dicoccum (Schrank) & Reichert, 1913 \\
Triticum sativum var.vulgare & Henry et al., 2011; Reichert, 1913 \\
Triticum turgidum Desf. & Henry et al., 2011 \\
Triticum urartu Tumanian ex Gandilyan & Piperno et al., 2004 \\
Vulpia persica (Boiss. \& Buhse) Krecz. \& Bobrov
\end{tabular}

Bibliography for Poaceae of Southwest Asia:

Henry, A. G., A. S. Brooks, D. R. Piperno. 2011. Microfossils in Calculus Demonstrate Consumption of Plants and Cooked Foods in Neanderthal Diets (Shanidar III, Iraq; Spy I and II, Belgium). Proceedings of the National Academy of Sciences 108:486-491.

Henry, A. G., H. F. Hudson, and D. R. Piperno. 2009. Changes in Starch Grain Morphologies from Cooking. Journal of Archaeological Science 36:915-922.

Messner, T. C. 2011. Acorns and Bitter Roots: Starch Grain Research in the Prehistoric Eastern Woodlands. University of Alabama Press, Tuscaloosa, AL.

Piperno, D. R., E. Weiss, I. Holst, and D. Nadel. 2004. Processing of Wild Cereal Grains in the Upper Palaeolithic Revealed by Starch Grain Analysis. Nature 430:670-673.

Messner (2011) analyzes starch grains in seeds and underground storage organs (USOs) produced by taxa that grow in the Delaware River valley, USA. Two of these taxa, Typha latifolia L. (cattail) and Cyperus esculentus L. (yellow nutsedge), are also found in Southwest Asia (Davis 1965; Migahid 1988). Finally, a few Southwest Asian taxa are discussed in experimental archaeological publications where researchers examine how food-processing activities affect starch grain morphology and how these changes can be detected archaeologically (Ge et al. 2010; Henry et al. 2009).

Food and plant science research on Southwest Asian taxa is extensive, focusing on understanding the chemical and physical attributes of main Southwest Asian domesticates: Triticum spp. (wheat), Hordeum spp. (barley), Secale spp. (rye), Vicia faba L. (faba bean), Lens culinaris Medikus (lentil), Pisum sativum L. (pea), and Cicer arietinum L. (chickpea). Other domesticates, such as Vicia sativa (common vetch) and Vicia ervilia (bitter vetch), have received little attention.

Reichert (1913) provides the most comprehensive analysis of starch grains produced by taxa and remains one of the seminal publications used by many paleoethnobotanists. In this publication, he reviews the state of starch grain research at the beginning of the $20^{\text {th }}$ century, discusses the chemical and physical properties of specific taxa, and provides an assessment on how these taxa can be identified based on their chemical and physical characteristics. Many of the taxa that he describes are found in Southwest Asia and can be referenced by comparing the list of species he covers with the species listed in one of the regional floras such as the Flora of Turkey and East Aegean Islands (Davis 1965).

\section{Materials and Methods}

Selecting species for analysis

Sixty-four species representing 22 families that currently grow in Syria were collected from Professor Joy McCorriston's extensive Southwest Asian herbarium collection at Ohio State University. The 64 species were subdivided into their constituent parts resulting in eighty-two samples (Tables 2 and 3). These samples included seeds, pericarps, synconia, legumes, and legume capsules. In this study, the generic term "seed" is used for simplicity. No leaves, stems, or small roots 


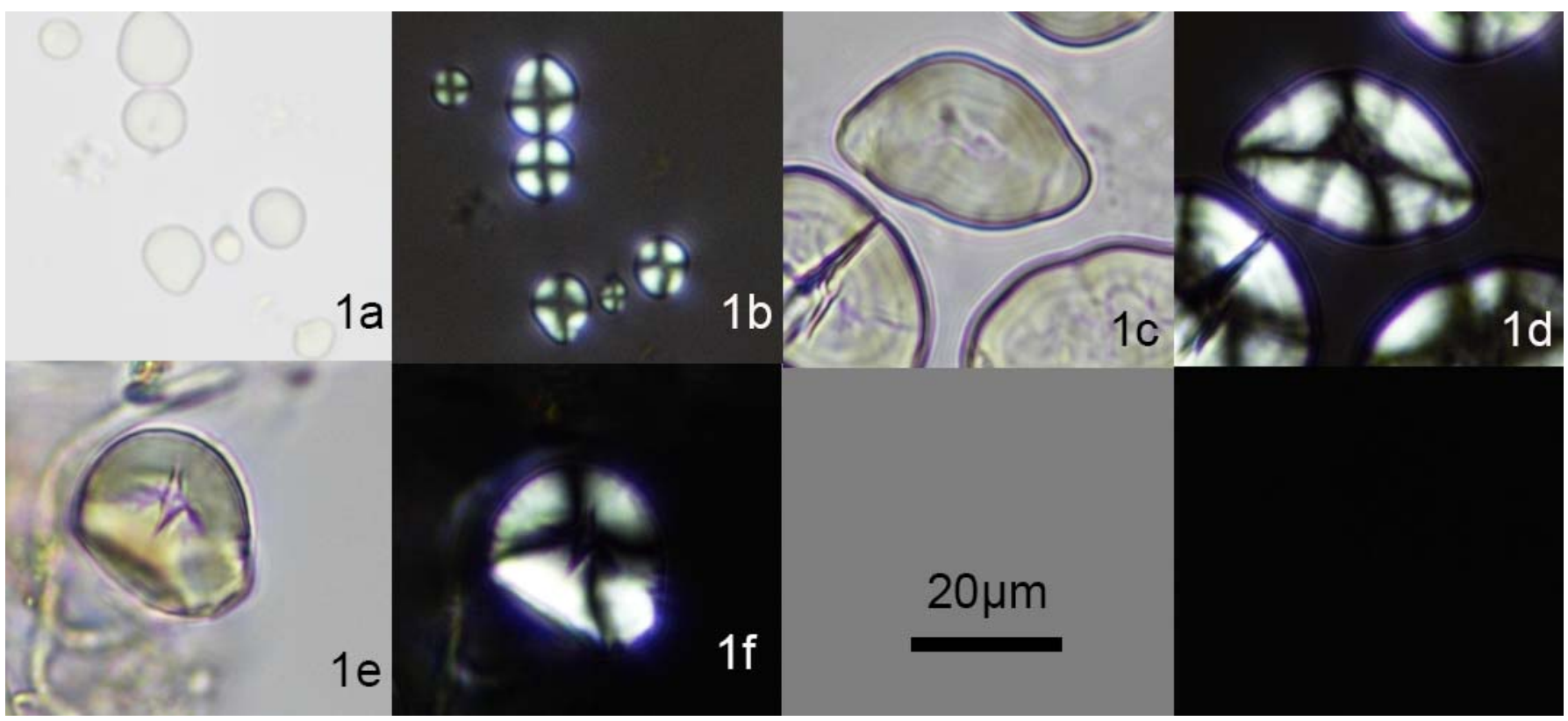

Figure 1. Transmitted and polarized views of starch at $400 \times$ magnification from: a, b) Cyperus esculentus; c, d) Vicia ervilia; and e, f) Moringa peregrina.

were analyzed because they rarely produce large storage starch grains (Haslam 2004). Underground storage organs of important wetland taxa from the Cyperaceae family (Ryan 2011) were not available for analysis because they are difficult to store and are rarely found in herbarium collections.

\section{Processing the samples}

Samples were cleaned according to the protocol outlined by Pearsall (2000: 436-437), cut into small pieces using a sterile scalpel, or gently crushed using a sterile mortar and pestle. Very little pressure was applied when using the mortar and pestle to minimize potential damage to the starch grains. Two drops of a one to one glycerol/distilled water mix were placed on a $25 \times 75 \times 1 \mathrm{~mm}$ microscope slide for each comparative sample. This medium was chosen, as opposed to a more permanent medium such as Permount or Entellen, in order to allow potential starch grains to be rotated when examined. The sample was gently covered with a microscope cover slip and the edges were sealed using finger nail polish and allowed to dry before being examined.

\section{Recording methods}

Samples were examined at $500 \times$ magnification using a Zeiss AxioStar Plus microscope. Each starch grain was given an identification number, described according to terms defined in the International Code for Starch Grain Nomenclature (ICSN 2014) and measured using NIS Elements software. Photos of individual starch grains were taken at the Environmental Archaeology Lab at University of Texas. In order to minimize researcher bias, starch grains were chosen at random for description by using the random number generator function within Excel to provide $x$ and $y$ coordinates on the microscope stage. Fifty simple or half compound starch grains were described and photographed when present for each sample. Compound and aggregate starch grains were noted although excluded from the total count because clustering would often obscure their optical attributes making the individual starch grains difficult to describe and quantify. Starches less than five microns were typically omitted because their optical attributes were often hard to distinguish. Starch grains less than five microns in length were only counted in instances where they constituted the bulk of the starch grains produced.

\section{Results}

Ten of 64 species produced starch grains. All of the starches were produced in the seeds with the exception of Moringa peregrina (Forssk.) Fiori (Yusor tree) that concentrated its starch in the pericarp (Table 2). The 54 species that did not produce starch grains were from wild taxa that were related to the domesticated grains and legumes or from other types of domesticat- 
Table 2. Taxa that produced starch grains in abundance in this study.

\begin{tabular}{lll}
\hline Family & Genus/Species & Plant Part \\
\hline Cyperaceae & Cyperus esculentus L. & Seed \\
Fabaceae (Leguminosae) & Vicia ervilia & Legume \\
Moringaceae & Moringa peregrina & Pericarp \\
Poaceae (Gramineae) & Aegilops crassa Boiss & Seed \\
& Aegilops triaristata Willd. & Seed \\
& Aegilops vavilovii (Zhuk.) Chennav. & Seed \\
& Hordeum distichon L. & Seed \\
& Pennisetum americanum (L.) Leeke & Seed \\
& Triticum compactum Host. & Seed \\
& Triticum durum Desf. & Seed \\
\hline
\end{tabular}

ed taxa (Table 3). These taxa produced seeds that were very small and contained almost no starches.

\section{Cyperus esculentus}

The starches formed within Cyperus esculentus (yellow nutsedge) seeds have a mean length of four microns, range in size from one to eight microns and are mostly ovoid in shape (Figure 1a, b). They differ markedly in size and shape from the starches produced in the tuber or root-stock, which have an average length of 12 to $14 \mathrm{~mm}$ and are conical to oval in shape (Reichert 1913). The seed starches are diagnostic to Cyperaceae because of their size and rounded, oval, compressed lenticular, angular, or polyhedral shapes that are commonly associated with other Cypereraceae seeds discussed in Reichert (1913).

Vicia ervilia

Vicia ervilia (bitter vetch) starches have an average length of $16 \mathrm{~mm}$ and range in size from five to $27 \mathrm{~mm}$ (Reichert 1913) (Figure 1c, d). Vicia ervilia starches from seeds can be identified to the family level because they exhibit what Reichert (1913) refers to as "bean type" features (spherical to ovoid in shape, half to as broad as long, slightly compressed with a distinct longitudinal cleft) that are characteristic of the Fabaceae (Leguminosae) family. These starches are mostly ovoid to elliptical and reniform shape and have deep longitudinal clefts.

\section{Moringa peregrina}

Moringa peregrina starches are mostly angular rounded, range in size from four to $27 \mathrm{~mm}$, and have an average length of ten microns (Figure 1. e, f). It is hard to determine if these starches are diagnostic because there are no close relatives discussed in Reichert (1913) or any of the other publications mentioned in this study. More studies should be conducted on
Moringa and closely related taxa to determine the diagnostic status of these starches. It is important to note that starch grains were extracted from the pericarp of the M. peregrina sample, and not the seed. This species suggests that tissues surrounding the seed, and not just the seed itself, need to be studied when conducting comparative starch grains research.

Aegilops crassa, A. triaristata, Hordeum distichon, Triticum durum, and $\mathrm{T}$. compactum

The seeds from the species Aegilops crassa (Persian goatgrass) (Figure 2a, b), A. triaristata (three awn-goat

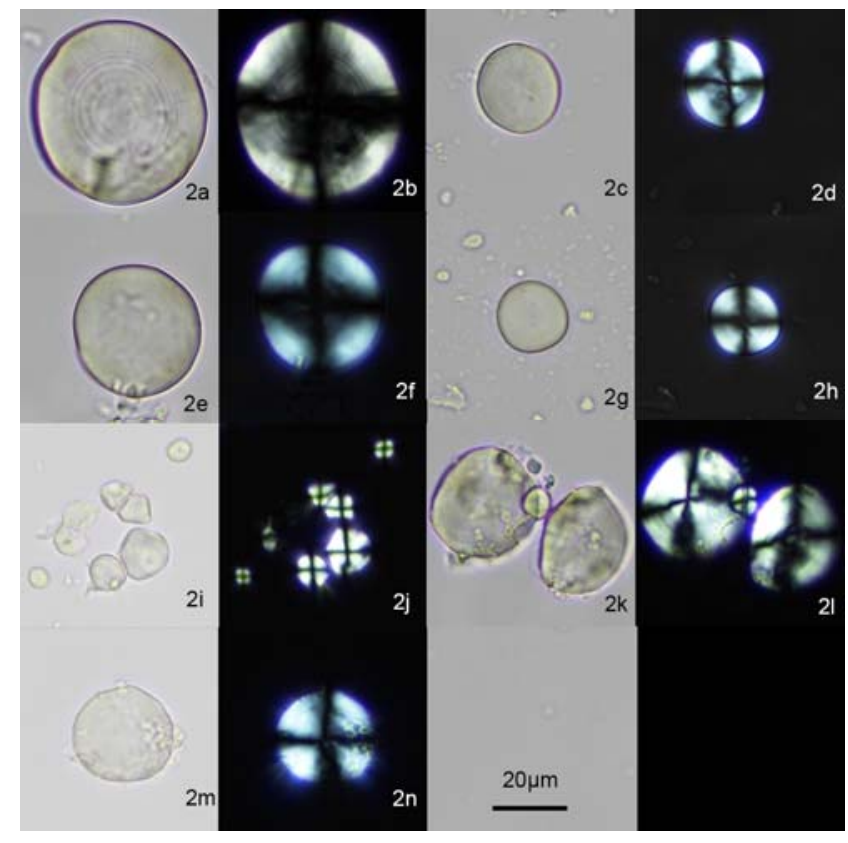

Figure 2. Transmitted and polarized views of starch at 400× magnification from: a, b) Aegilops crassa; c, d) Aegilops triaristata; e, f) Aegilops vavilovii; g, h) Hordeum distichon; i, j) Pennisetum americanum; k, l) Triticum durum; and $\mathrm{m}, \mathrm{n}$ ) Triticum compactum. 
Table 3. Taxa that did not produce abundant starch grains.

\begin{tabular}{|c|c|c|}
\hline Family & Genus/Species & Plant Part \\
\hline \multirow[t]{5}{*}{ Anacardiaceae } & Pistacia atlantica Desf. & Seed \\
\hline & Pistacia khinjuk Stocks & Seed \\
\hline & Pistacia palaestina Boiss. & Seed \\
\hline & Pistacia terebinthus L. & Seed \\
\hline & Rhus coriaria L. & Seed \\
\hline \multirow[t]{2}{*}{ Apiaceae (Umbelliferae) } & Bupleurum lancifolium Hornem. & Seeds \\
\hline & Cuminum cyminum L. & Seeds \\
\hline Arecaceae (Palmae) & Phoenix dactylifera $\mathrm{L}$. & Seed \\
\hline \multirow[t]{7}{*}{ Asteraceae (Compositae) } & Carthamus tinctorius L. & Seed \\
\hline & Guizotia abyssinica (L.) Cass. & Seed \\
\hline & Helianthus annus L. & Seed \\
\hline & Notobasis syriaca (L.) Cass. & Seed \\
\hline & Onopordum illyricum L. & Seed \\
\hline & Onopordum palaestinum Eig. & Seed \\
\hline & Silybum marianum (L.) Gaertn & Seed \\
\hline Euphorbiaceae & Chorozophora tinctoria (L.) A. Juss. & Seed \\
\hline \multirow[t]{7}{*}{ Fabaceae (Leguminosae) } & Acacia farnesiana (L.) Willd. & legume \\
\hline & Acacia nilotica (L.) Delile & Seed \\
\hline & Hymenocarpos circinnatus (L.) Savi & Legume \\
\hline & Prosopis farcta Banks \& Sol.) J. F. Macbr. & Legume capsule \\
\hline & Trigonella foenum-graecum $\mathrm{L}$. & Legume \\
\hline & Trigonella monantha C. A. Mey. & Legume \\
\hline & Trigonella stellata Forssk. & Legume \\
\hline \multirow[t]{2}{*}{ Geraniaceae } & Erodium ciconium (L.) L'Hér. ex Aiton & Seed \\
\hline & Erodium gruinum (L.) L'Hér. ex Aiton & Seed \\
\hline Malvaceae & Malva parviflora $\mathrm{L}$. & Seed \\
\hline Moraceae & Ficus carica $\mathrm{L}$. & Synconium, seed \\
\hline Moringaceae & Moringa peregrina (Forssk.) Fiori & Seed \\
\hline Oleaceae & Olea europaea L. & Pericarp, seed \\
\hline Pedaliaceae & Sesamum indicum L. & Seed \\
\hline Poaceae & Bromus scoparius Scop. & Seed \\
\hline \multirow[t]{2}{*}{ Polygonaceae } & Polygonum patulum M. Bieb & Seed \\
\hline & Polygonum venantianum Clementi & Seed \\
\hline Ranunculaceae & Adonis dentata Delile & Seed \\
\hline \multirow[t]{2}{*}{ Rhamnaceae } & Rhamnus palaestinus Boiss. & Pericarp, seed \\
\hline & Zizyphus spina-christi (L.) Desf. & Exocarp, pericarp, seed \\
\hline \multirow[t]{3}{*}{ Rosaceae } & Amygdalus arabica (Oliv.) & Pericarp, seed \\
\hline & Amygdalus communis $\mathrm{L}$. & Pericarp, seed \\
\hline & Amygdalus orientalis Mill. & Exocarp, pericarp, seed \\
\hline
\end{tabular}

(continued on next page) 
(continued from previous page)

\begin{tabular}{lll}
\hline Family & Genus/Species & Plant Part \\
\hline & Crataegus aronia (L.) DC & Pericarp, seeds \\
& Prunus domestica L. & Seeds \\
& Prunus mahaleb L. & Seeds \\
& Prunus persica (L.) Stokes & Pericarp, seed \\
& Rosa canina L. & Pericarp/seed, seeds \\
& Rosa phoenicea Boiss. & Pericarp, seeds \\
Rubiaceae & Sarcopoterium sinposum (L.) Spach. & Seeds \\
& Asperula arvensis L. & Seeds \\
Solanaceae & Coffea arabica L. & Beans \\
& Galium tricornutum Dandy & Seeds \\
& Hyscamus muticus L. & Seed \\
& Physalis alkekengi L. & Seed \\
Urticaceae & Physalis angulata L. & Pericarp \\
Zygophllaceae & Solanum sepicula Dunal & Seed, fruit \\
\hline & Urtica pilulifera L. & Seed \\
& Balanites aegyptiaca (L.) Delile & Exocarp, pericarp, seed \\
\hline
\end{tabular}

grass) (Figure 2c, d), Hordeum distichon (two-rowed barley) (Figure 2g, h), Triticum durum (durum wheat) (Figure 2k, 1), and T. compactum (club-wheat) (Figure $2 \mathrm{~m}, \mathrm{n})$ in this study all exhibit features that are diagnostic of the tribe Triticeae within the Poaceae (Gramineae) family. In general, starch grains from this tribe have simple, lenticular, oval, kidney (reniform) or dicoid in shapes with small reticulate surface depressions (Piperno et al. 2004; Yang and Perry 2013). The five Triticeae taxa that yielded abundant starch grains within this study exhibited all of these features

Seed starch grains from Aegilops, Hordeum, and Triticum taxa (AHT) and the Triticeae tribe are also much larger in general than the seed starch grains from non-Triticeae taxa. This feature can be used to identify individual starches at least to the tribe level when shape and size attributes are analyzed together. The mean length for the Poaceae starch grains observed in this study follow the pattern observed by Piperno et al. (2004) where AHT taxa can be distinguished from other grass taxa, such as the Pennisetum americanum, based on their overall large size (Table 4). The average length of the 18 AHT seed starch grain taxa in Table 4 with a sample size of 50 is $17.7 \mathrm{~mm}$ with a standard deviation of $5.7 \mathrm{~mm}$. This length is well above the average length of the 15 non-Triticeae with an average of $5.1 \mathrm{~mm}$ and a standard deviation 2.6mm. Recent work by Yang and Perry (2013) on 38 grass species from China supports this hypothesis and goes one step further, suggesting that all members of the tribe Triticeae produce larger starches relative to other Poaceae.

The one non-Triticeae grass in this study that yielded abundant seed starch, Pennesitum americanum yielded semi-compound to compound, flat, angular, or irregular shaped starch grains (Figure 2. i, j). This compares well with other studies of non-Triticeae grasses such as Bromus sp. and Pipatherum sp. where similar features were observed (Piperno et al. 2004).

\section{Discussion and Conclusions}

Chemical and physical properties of starch grains from over 100 species from Southwest Asia have been published in archaeological reports and food and plant science literature. An additional 64 species were examined here, ten of which produced abundant starch grains in their seeds and pericarps that are diagnostic at the tribe, family, and potentially genus and species level. This project adds to the growing body of knowledge regarding archaeological starch grain analysis in Southwest Asia by centralizing the published comparative literature for this region and describing the starches produced in domesticated and wild taxa.

The starches from Cyperus esculentus seeds are 
Table 4. Mean ( \pm s.d.) length $(\mathrm{mm})$ and range for Poaceae starch grains divided by subfamily and tribe.

\begin{tabular}{|c|c|c|c|c|c|c|}
\hline Subfamily & Tribe & Genus/species & Mean & Range & $\mathrm{n}$ & Source \\
\hline Panicodae & Paniceae & Pennisetum americanum (L.) Leeke & $5.7(1.4)$ & $3-10$ & 50 & This study \\
\hline \multirow[t]{26}{*}{ Pooideae } & Aveneae & Alopecurus arundinaceus Poir. & $4(0.9)$ & $2-8$ & 50 & $\begin{array}{l}\text { Piperno et al } \\
2004\end{array}$ \\
\hline & & Alopecurus utriculatus Banks \& Sol. & $5(1.5)$ & $2-8$ & 50 & $\begin{array}{l}\text { Piperno et al } \\
2004\end{array}$ \\
\hline & & Avena barbata Pott ex Link & $12(2.9)$ & $6-18$ & 50 & $\begin{array}{l}\text { Piperno et al } \\
2004\end{array}$ \\
\hline & & $\begin{array}{l}\text { Gastridium ventricosum (Gouan) Schinz \& } \\
\text { Thell. }\end{array}$ & $4(1.0)$ & $2-6$ & 50 & $\begin{array}{l}\text { Piperno et al } \\
2004\end{array}$ \\
\hline & & Phalaris minor Retz. & $<2.0$ & - & 50 & $\begin{array}{l}\text { Piperno et al } \\
2004\end{array}$ \\
\hline & & Phalaris paradoxa $\mathrm{L}$. & $<4.0$ & - & 50 & $\begin{array}{l}\text { Piperno et al } \\
2004\end{array}$ \\
\hline & Brachypodieae & Brachypodium distachyon (L.) P.Beauv. & $9(2.2)$ & $4-16$ & 50 & $\begin{array}{l}\text { Piperno et al } \\
2004\end{array}$ \\
\hline & Bromeae & Bromus pseudobrachystachys H. Scholz & $5(1.4)$ & $4-8$ & 50 & $\begin{array}{l}\text { Piperno et al } \\
2004\end{array}$ \\
\hline & Poeae & Lolium multiflorum Lam. & $<6.0$ & - & 50 & $\begin{array}{l}\text { Piperno et al } \\
2004\end{array}$ \\
\hline & & Lolium rigidum Gaudin & $<6.0$ & - & 50 & $\begin{array}{l}\text { Piperno et al } \\
2004\end{array}$ \\
\hline & & Puccinellia distans (Jacq.) Parl. & $<4.0$ & - & 50 & $\begin{array}{l}\text { Piperno et al } \\
2004\end{array}$ \\
\hline & & Puccinellia gigantea (Grossh.) Grossh. & $<4.0$ & - & 50 & $\begin{array}{l}\text { Piperno et al } \\
2004\end{array}$ \\
\hline & & $\begin{array}{l}\text { Vulpia persica (Boiss. \& Buhse) Krecz. \& } \\
\text { Bobrov }\end{array}$ & $<2.0$ & - & 50 & $\begin{array}{l}\text { Piperno et al } \\
2004\end{array}$ \\
\hline & Stipeae & $\begin{array}{l}\text { Piptatherum holciforme (M.Bieb.) Roem. } \\
\text { \& Schult. }\end{array}$ & $3(1.0)$ & $2-4$ & 50 & $\begin{array}{l}\text { Piperno et al } \\
2004\end{array}$ \\
\hline & Triticeae & Aegilops crassa Boiss & $16(7.6)$ & $5-31$ & 50 & This study \\
\hline & & Aegilops geniculata Roth & $21(6.4)$ & $10-36$ & 50 & $\begin{array}{l}\text { Piperno et al } \\
2004\end{array}$ \\
\hline & & Aegilops peregrina Hack. & $25(8.0)$ & $12-52$ & 50 & $\begin{array}{l}\text { Piperno et al } \\
2004\end{array}$ \\
\hline & & Aegilops speltoides Tausch & $22(4.5)$ & $10-32$ & 50 & Henry et al 2011 \\
\hline & & Aegilops triaristata Willd. & $10(3.4)$ & $5-20$ & 50 & This study \\
\hline & & Aegilops vavilovii (Zhuk.) Chennav. & $13(6.2)$ & $5-35$ & 50 & This study \\
\hline & & Hordeum bulbosum L. & $17(3.7)$ & $10-24$ & 50 & $\begin{array}{l}\text { Piperno et al } \\
2004\end{array}$ \\
\hline & & Hordeum bulbosum (with lamellae only) & $21(1.6)$ & $18-24$ & 50 & $\begin{array}{l}\text { Piperno et al } \\
2004\end{array}$ \\
\hline & & Hordeum distichon L. & $11(2.7)$ & $5-18$ & 50 & This study \\
\hline & & Hordeum glaucum Steudel & $18(3.5)$ & $10-30$ & 39 & Henry et al 2011 \\
\hline & & Hordeum glaucum Steudel & $18(3.9)$ & $8-24$ & 50 & $\begin{array}{l}\text { Piperno et al } \\
2004\end{array}$ \\
\hline & & Hordeum glaucum (with lamellae only) & $22(1.4)$ & $18-26$ & 50 & $\begin{array}{l}\text { Piperno et al } \\
2004\end{array}$ \\
\hline
\end{tabular}

(continued on next page) 
(continued from previous page)

\begin{tabular}{|c|c|c|c|c|c|c|}
\hline Subfamily & Tribe & Genus/species & Mean & Range & $\mathbf{n}$ & Source \\
\hline \multirow[t]{11}{*}{ Pooideae } & Triticeae & Hordeum hexastichon L. & $20(3.5)$ & $10-30$ & 52 & Henry et al 2011 \\
\hline & & Hordeum marinum Huds. & $10(1.8)$ & $6-14$ & 50 & $\begin{array}{l}\text { Piperno et al } \\
2004\end{array}$ \\
\hline & & Hordeum spontaneum L. & $18(3.8)$ & $12-30$ & 27 & Henry et al 2011 \\
\hline & & Hordeum spontaneum L. & $20(4.7)$ & $10-26$ & 50 & $\begin{array}{l}\text { Piperno et al } \\
2004\end{array}$ \\
\hline & & $\begin{array}{l}\text { Hordeum spontaneum (with lamellae } \\
\text { only) }\end{array}$ & $28(2.9)$ & $18-26$ & 50 & $\begin{array}{l}\text { Piperno et al } \\
2004\end{array}$ \\
\hline & & Secale vavilovii Grossh. & $25(4.2)$ & $15-36$ & 50 & Henry et al 2011 \\
\hline & & Triticum aestivum $\mathrm{L}$. & $24(4.4)$ & $15-35$ & 52 & Henry et al 2011 \\
\hline & & Triticum compactum Host. & $12(4.9)$ & $5-22$ & 50 & This study \\
\hline & & Triticum dicoccoides Schrank ex Schübl. & $17(6.1)$ & $8-30$ & 50 & $\begin{array}{l}\text { Piperno et al } \\
2004\end{array}$ \\
\hline & & Triticum durum Desf. & $11(4.0)$ & $5-23$ & 50 & This study \\
\hline & & $\begin{array}{l}\text { Triticum monococcum subsp. aegilo- } \\
\text { poides (Link.) Thell. }\end{array}$ & $15(1.7)$ & $10-20$ & 46 & Henry et al 2011 \\
\hline
\end{tabular}

distinct from the starches produced in its tubers but are similar to the seeds of other related taxa within the Cyperaceae family making them diagnostic to this family. Vicia ervilia starches exhibit "bean type" features and can be identified to the genus and species level due to their small size and Fabaceae (Leguminosae)-like properties. Although the diagnostic ability of Moringa peregrina starches remains unclear, their production in the pericarp, and not the seed challenges assumptions originally made in this project, and in the general literature, about perceived starch production in particular plant parts and illustrates the importance of testing every part of a plant when possible. Finally, the Poaceae taxa in this study can be distinguished from each other at the tribe level by size and overall shape.

Centralization of information about taxa that produce starch grains will help specialists narrow down identification of unknown starch grains encountered in the archaeological record. The discovery of starch grains within important domesticated taxa such as Hordeum distichon, Triticum durum, and wild taxa such as Cyperus esculentus provides a clearer understanding of what can be identified within Southwest Asia and within these families and genera.

There are many avenues of comparative starch grain research that can be pursued to better aid archaeologists in their reconstruction of plant use in Southwest Asia. With a few exceptions, very little research has been conducted on starch grains pro- duced by underground storage organs such as bulbs, corms, rhizomes, and tubers (Henry et al. 2009, 2011; Messner 2011; Piperno et al. 2004; Reichert 1913; Yang and Perry 2013). Macrobotanical and phytolith evidence suggests that wetland taxa played an important role as a source of food in Southwest Asia during the Epipaleolithic (Wollstonecroft et al. 2008), Pre-Pottery Neolithic (Balbo et al. 2012), Pottery Neolithic (Rosen 2005), and Ubaid (Kennett and Kennett 2006) periods. Aside from the research by Hather (1991, 1993), very little work has been conducted to establishd criteria for identifying underground storage organs at archaeological sites. Recovering and identifying starch grains associated with USO's would open a whole new avenue of research into wild resource exploitation, complement existing datasets, and allow for archaeologists to explore new topics through the analysis of starches contained in artifact residues and dental calculus.

The research on Triticeae taxa from China (Yang and Perry, 2013) and taxa from the Delaware River Valley, USA (Messner 2008, 2011) are excellent examples of how a regional synthesis can lead to the construction of standardized dichotomous keys for a region. In both of these papers, the researchers develop an easy to use dichotomous key that allows for quick identification of archaeological starch grains. Further research into starch grain production patterns of other taxa found in Southwest Asia and the identification of Southwest Asian taxa discussed in Reichert (1913) would eventually lead to the develop- 
ment of a dichotomous key and the establishment of regional diagnostic starch grain types that archaeologists could use in this important area of the world.

\section{Acknowledgements}

I owe Professor Joy McCorriston a massive debt of gratitude for allowing me to study and use her Near Eastern macrobotanical comparative collection for this project. I would also like to thank Masoumeh Kimiaie and Matthew Senn for their assistance and hospitality while working in the McCorriston Laboratory at Ohio State University. This project would not have been possible without the aid of my undergraduate assistants Kathleen Hammel, Andrew Ritz, Joyce Fountain, Stephen McKay, and Jessica Lundquist. Without them, I never would have been able to create and study such a wonderful starch grain comparative collection. Finally, thank you to my committee members Dr. Alexia Smith, Dr. Natalie Munro, Professor Deborah Pearsall, Professor Gil Stein, and Professor Sally McBrearty, as well as the anonymous reviewers for the helpful comments on the manuscript.

\section{Declarations}

Permissions: None declared.

Sources of funding: National Science Foundation Dissertation Improvement Grant.

Conflicts of interest: None declared.

\section{References Cited}

Balbo, A. L., E. Iriarte, A. Arranz, L. Zapata, C. Lancelotti, M. Madella, L. Teira, M. Jiménez, F. Braemer, and J. J. Ibáñez. 2012. Squaring the Circle. Social and Environmental Implications of Pre-Pottery Neolithic Building Technology at Tell Qarassa (South Syria). PLoS One 7:e42109-e42109.

Cummings, L. S., and A. Magennis. 1997. A phytolith and starch record of food and grit in Mayan human tooth tartar. In Estado Actual De Los Esudios De Fitolitos en Suelos Y Plantas, edited by A. Pinilla, J. Juan-Tresserras, and M. J. Machado, pp. 211-218. Centro de Ciencias Medioambientales, Madrid.

Davis, P. H. ed. 1965. Flora of Turkey and the East Aegean Islands, Vol 1. Edinburgh University Press, Edinburgh.

Duncan, N. A., D. M. Pearsall, and R. A. Benfer, Jr.
2009. Gourd and Squash Artifacts Yield Starch Grains of Feasting Foods from Preceramic Peru. Proceedings of the National Academy of Sciences 106:13202 $-13206$.

Ge, W., L. Liu, X. Chen, J. Zhengyao. 2010. Can Noodles Be Made From Millet? An Experimental Investigation of Noodle Manufacture Together with Starch Grain Analyses. Archaeometry 53:194-204.

Gott, B., H. Barton, D. Samuel, and R. Torrence. 2006. Biology of Starch, In Ancient Starch Research, edited by R. Torrence, and H. Barton, pp. 35-45. Left Coast Press, Walnut Creek, CA.

Haslam, M. 2004. The Decomposition of Starch Grains in Soils: Implications for Archaeological Residue Analyses. Journal of Archaeological Science 31:1715-1734.

Hather, J. G. 1991. The Identification of Charred Archaeological Remains of Vegetative Parenchymous Tissue. Journal of Archaeological Science 18:661675.

Hather, J. G. 1993. An Archaeobotanical Guide to Root and Tuber Identification: Europe and South West Asia. Oxbow Books Limited, Oxford.

Henry, A. G., A. S. Brooks, and D. R. Piperno. 2011. Microfossils in Calculus Demonstrate Consumption of Plants and Cooked Foods in Neanderthal Diets (Shanidar III, Iraq; Spy I and II, Belgium). Proceedings of the National Academy of the Sciences 108:486-491.

Henry, A. G., H. F. Hudson, and D. R. Piperno. 2009. Changes in Starch Grain Morphologies from Cooking. Journal of Archaeological Science 36:915-922.

Henry, A. G., and D. R. Piperno. 2008. Using Plant Microfossils from Dental Calculus to Recover Human Diet: A Case Study from Tell al-Raqā'i, Syria. Journal of Archaeological Science 35:1943-1950.

Horrocks, M., G. Irwin, M. Jones, and D. Sutton. 2004. Starch Grains and Xylem Cells of Sweet Potato (Ipomoea batatas) and Bracken (Pteridium esculentum) in Archaeological Deposits from Northern New Zealand. Journal of Archaeological Science 31:251-258.

ICSN. 2014. The International Code for Starch Nomenclature [WWW Document]. Foundation for Archaeobotanical Research in Microfossils. Available at: http://fossilfarm.org/ICSN/Code.html. Accessed on February 2, 2014. 
Kennett, D., and J. Kennett. 2006. Early State Formation in Southern Mesopotamia: Sea Levels, Shorelines, and Climate Change. The Journal of Island and Coastal Archaeology 1:67-99.

Li, M., X. X. Yang, H. Wang, Q. Wang, X. Jia, and Q. Ge. 2010. Starch Grains from Dental Calculus Reveal Ancient Plant Foodstuffs at Chenqimogou Site, Gansu Province. Science China Earth Sciences 53:694-699.

Messner, T. C. 2008. Woodland Period People and Plant Interactions: New Insights from Starch Grain Analysis. Unpublished Doctoral Dissertation, Department of Anthropology, Temple University, Philadelphia, PA.

Messner, T. C. 2011. Acorns and Bitter Roots: Starch Grain Research in the Prehistoric Eastern Woodlands. University of Alabama Press, Tuscaloosa, AL.

Migahid, Ahmed Mohammed. 1988. Flora of Saudi Arabia, Vol 1., King Saud University, Riyadh.

Parr, J. F., and M. Carter. 2003. Phytolith and Starch Analysis of Sediment Samples from Two Archaeological Sites on Dauar Island, Torres Strait, Northeastern Australia. Vegetation History and Archaeobotany 12:131-141.

Pearsall, D. M. 2000. Paleoethnobotany: A Handbook of Procedures, 2nd ed. Academic Press, San Diego, CA.

Perry, L. 2004. Starch Analyses Reveal the Relationship between Tool Type and Function: An Example from the Orinoco Valley of Venezuela. Journal of Archaeological Science 31:1069-1081.

Piperno, D. R., and T. D. Dillehay. 2008. Starch Grains on Human Teeth Reveal Early Broad Crop Diet in Northern Peru. Proceedings of the National Academy of Sciences 105:19622-19627.

Piperno, D. R., A. J. Ranere, I. Holst, and P. Hansell. 2000. Starch Grains Reveal Early Root Crop Horticulture in the Panamanian Tropical Forest. Nature 407:894-897.

Piperno, D. R., E. Weiss, I. Holst, and D. Nadel. 2004. Processing of Wild Cereal Grains in the Upper Palaeolithic Revealed by Starch Grain Analysis. Nature 430:670-673.

Riehl, S. 1999. Bronze Age Environment and Economy in the Troad: The Archaeobotany of Kumtepe and Troy. Unpublished Doctoral Dissertation, Faculty of Geosciences, University of
Tübingen, Tübingen, Germany.

Reichert, E. T. 1913. The Differentiation and Specificity of Starches in Relation to Genera, Species, Etc., Stereochemistry Applied to Protoplasmic Processes and Products and as a Strictly Scientific Basis for the Classification of Plants and Animals. The Carnegie Institute of Washington, Washington D. C.

Rosen, A. M. 2005. Phytolith Indicators of Plant and Land Use at Çatalhöyük, In Inhabiting Catalböyük; Reports From the 1995-99 Seasons, edited by I. Hodder, pp. 203-212. McDonald Institute of Archaeology, Cambridge.

Ryan, P. 2011. Plants as Material Culture in the Near Eastern Neolithic: Perspectives from the Silica Skeleton Artifactual Remains at Çatalhöyük. Journal of Anthropological Archaeology 30:292-305.

Samuel, D. 1996. Investigation of Ancient Egyptian Baking and Brewing Methods by Correlative Microscopy. Science 273:488-490.

Sivak, M. N. S., and J. Preiss, eds. 1998. Starch: Basic Science to Biotechnology. Academic Press, San Diego, CA.

Tester, R. F., J. Karkalas, and X. Qi. 2004. StarchComposition, Fine Structure and Architecture. Journal of Cereal Science 39:151-165.

Torrence, R., and H. Barton, eds. 2006. Ancient Starch Research. Left Coast Press, Walnut Creek, CA.

Wollstonecroft, M. M., P. R. Ellis, G. C. Hillman, and D. Q. Fuller. 2008. Advances in Plant Food Processing in the Near Eastern Epipalaeolithic and Implications for Improved Edibility and Nutrient Bioaccessibility: An Experimental Assessment of Bolboschoenus maritimus (L.) Palla (sea club-rush). Vegetetation History and Archaeobotany 17:19-27.

Yang, X., and L. Perry. 2013. Identification of Ancient Starch Grains from the Tribe Triticeae in the North China Plain. Journal of Archaeological Science 40:3170-3177.

Zohary, D., M. Hopf, M., and E. Weiss. 2012. Domestication of Plants in the Old World. Oxford University Press, Oxford.

\section{Biosketch}

Thomas C. Hart is the laboratory manager/research scientist for the Environmental Archaeology Laboratory at the University of Texas at Austin. 